\title{
Pelaksanaan Fungsi Pengawasan DPRD Terhadap Pemerintah Daerah Dalam Rangka Mewujudkan Good Governance
}

\section{Budiyono}

Dosen Bagian Hukum Tata Negara Fakultas Hukum Universitas Lampung

\begin{abstract}
Abstrak
Berhasilnya penyelenggaran pemerintahan daerah tergantung dari kinerja unsurunsur pemerintahan daerah.unsur -unsur pemerintahan daerah yaitu pemerintah daerah sebagai lembaga eksekutif daerah dan DPRD sebagai lembaga legislatf. Dewan Perwakilan Rakyat Daerah (DPRD) merupakan bagian dari Pemerintah Daerah yang memiliki fungsi legislasi, anggaran, dan pengawasan. Tugas DPRD secara normatif merupakan cerminan kehidupan demokrasi dalam pemerintahan daerah sebagai sarana cheek and balance serta diharapkan agar fungsi pengawasan yang dilakukan oleh DPRD dapat mewujudkan good governance. bahwa fungsi pengawasan DPRD terhadap pemerintah daerah memiliki peran yang sangat penting dalam mewujudkan Good Governance di Indonesia khususnya di daerah, karena bagaimanapun juga DPRD adalah lembaga perwakilan rakyat yang berada di daerah untuk menyampaikan aspirasi dan sudah sepantasnya rakyat juga ikut serta dalam mengawasi jalannya pemerintahan daerah yang tercermin dengan pelaksanaan fungsi pengawasan DPRD terhadap pemerintah daerah (eksekutif selaku pelaksana kebijakan). Dengan adanya pengawasan yang dilakukan oleh DPRD terhadap pemerintah daerah tentunya merupakan cerminan terlaksananya mekanisme checks and balances- dalam pengelolaan tata pemerintahan yang baik (good governace) di daerah.
\end{abstract}

Kata kunci : Pengawasan DPRD, pemerintah daerah, fungsi pengawasan

\section{Pendahuluan}

Negara Republik Indonesia dalam Undang-Undang Dasar (UUD) Tahun 1945 didesain sebagai Negara Kesatuan. Karenanya, kedaulatan adalah tunggal atau terpusat, tidak tersebar atau terbagi-bagi pada negara bagian seperti dalam negara federal/serikat tetapi Indonesia adalah Negara kesatuan yang menganut desentralisasi ${ }^{1}$ dalam

2 M. Laica Marjuki, Berjalan-Jalan di Ranah Hukum: Otonomi Daerah Dalam Perspektif Negara Kesatuan, Sekjend MK RI, 2006. Hlm. 159 penyelenggaraan pemerintahan. Sistem Pemerintahan Daerah di Indonesia, menurut UUD 1945 yang menjadi dasar penyelenggaraan pemerintahan baik di pusat maupun di daerah dalam Perubahan Kedua UUD 1945 tentang Pemerintahan Daerah dalam pasal 18, dinyatakan sebagai berikut:

(1) Negara Kesatuan Republik Indonesia dibagi atas daerahdaerah propinsi dan daerah Propinsi itu atas kabupaten dan kota, yang tiap-tiap propinsi, kabupaten, dan kota itu mempunyai pemerintahan daerah, 
yang diatur dengan undangundang.

(2) Pemerintah daerah propinsi, daerah kabupaten, dan kota mengatur dan mengurus

(3) sendiri urusan pemerintahan menurut asas otonomi dan tugas pembantuan.

(4) Pemerintahan ddaerah propinsi, kabupaten, dan kota memiliki Dewan Perwakilan Rakyat Daerah yang anggotaanggotannya dipilih melalui pemilihan umum

(5) Gubernur, bupati, dan walikota masing-masing sebagai kepala pemerintahan daerah propinsi, kabupaten, dan kota dipilih secara demokratis.

Sehubungan dengan itu, UUD 1945 menggariskan tentang pembagian kekuasaan baik secara vertikal maupun horizontal. Pembagian secara vertikal lazim dikenal sebagai pembagian kekuasaan antara beberapa tingkat pemerintahan, sementara pembagian secara horizontal menunjuk pada pembagian fungsi-fungsi antara organ-organ kenegaraan. ${ }^{2}$

Dalam Pasal 18A UUD 1945, diamanatkan hubungan wewenang antara pemerintah pusat dan pemerintahan daerah propinsi, kabupaten , dan kota, atau antara propinsi, kabupaten serta kota, diatur dengan undang-undang dengan memperhatikan kekhususan dan keragaman daerah. Disamping itu, hubungan keuangan, pelayanan umum, pemanfaatan sumber daya alam, serta sumber daya lainya antara pemerintah pemerintah pusat dan pemerintah daerah diatur dan

2 Juanda, Hukum Pemerintahan Daerah: Pasang Surut Kewenangan antara DPRD dan Kepala Daerah, Penerbit P.T. Alumni, Bandung, 2004, halaman 1 dilaksanakan secara adil dan selaras berdasarkan undang-undang.

Perubahan terhadap Pasal 18 tersebut dapat dilihat sejumlah paradigma penyelenggaraan pemerintahan daerah, paradigma yang dimaksud adalah : ${ }^{3}$

1) Pemerintahan daerah disusun dan dijalankan berdasarkan otonomi dan tugas pembantuan (belaka). Dimasa depan tidak ada lagi pemerintahan dekonsentrasi dalam pemerintahan daerah

2) Pemerintahan daerah disusun dan dijalankan atas dasar otonomi seluas-luasnya. Semua fungsi pemeritahaan di bidang administrasi negara (administratief regelen en bestur) dijalankan oleh pemerintah daerah, kecuali yang ditentukan oleh pemeriintah pusat;

3) Pemerintahan daerah disusun dan dijalankan atas dasar keragaman daerah. Urusan rumah tangga tidak perlu seragam. Peerbedaan harus dimungkinkan baik atas dasar kultural, sosial, ekonomi, geografi, dan lain sebagainya;

4) Pemerintahan daerah disusun dan dijalankan dengan mengakui dan menghormati kesatuan masyarakat hukum adat (adatrechts gemeenschap) dan berbagai hak tradisionalnya. Satuan pemerintah asli dan hakhak masyarakat asli atas bumi, air, dan lain-lain wajib dihormati untuk sebesar-besarnya kemakmuran dan kesejahteraan rakyat setempat.

5) Pemerintahan daerah dapat disusun dan dijalankan berdasarkan sifat atau keadaan

3 Bagir Manan, Menyongsong Fajar Otonomi Daerah. Pusat Studi Hukum (PSH), Fakultas Hukum UII Yogyakarta, 2001. halaman 229 
khusus tertentu baik atas kedudukan (seperti Ibi kota Negara), kesejarahan (seperti D.I. Yogyakarta), atau karena keadaan sosial kultural (seperti D.I. Aceh dan Papua)

6) Anggota DPRD dipilih langsung dalam suatu pemilihan umum. Dimasa depan tidak ada lagi anggota DPRD (begitu juga anggota DPR ) yang diangkat. ${ }^{4}$

7) Hubungan Pusat dan Daerah dilaksanakan secara selaras dan adil.

Perubahan paradigma dalam penyelenggaraan pemerintahaan daerah ini terjadi karena adanya perubahan dalam sistem ketatanegaraan kita yang lebih demokratis sehingga menghasilkan produk hukum yang responsif terhadap tuntutan-tuntutan baik individu maupun berbagai kelompok sosial di dalam masyarakat sehingga lebih mampu mencerminkan rasa keadilan di dalam masyarakat. ${ }^{5}$

\footnotetext{
${ }^{4}$ Pasal 24 ayat (5) Undang-Undang Nomor 32 Tahun 2004 tentang Pemerintahan Daerah menegaskan bahwa: "Kepala Daerah dan Wakil Kepala Daerah sebagaimana dimaksud pada ayat (2) dan ayat (3) dipilih dalam satu pasangan secara langsung oleh rakyat di daerah yang bersangkutan

5 Moh. Mahfud M.D., Pergulatan Politik dan Hukum Di Indonesia, Penerbit Gama Media, Yogyakarta, 1999, hlm. 9. Mahfud menjelaskan bahwa konfigurasi politik yang demokratis akan konfigurasi yang akan membuka peluang bagi berperannya potensi rakyat secara maksimal untuk turut aktif dalam menentukan kebijakan Negara dan produk hukum yang dihasilkan dari konfigurasi politik yang demokratis adalah produk hukum yang karakternya mencerminkan pemenuhan atas tuntutantuntutan baik individu maupun berbagai kelompok sosial di dalam masyarakat sehingga lebih mampu mencerminkan rasa keadilan di dalam masyarakat, sedangkan konfigurasi politik yang otoriter adalah konfigurasi politik yang menempatkan pemerintah pada posisi yang lebih dominant
}

Penyelenggaraan pemerintahan daerah di Indonesia sebagaimana yang diamanatkan UUD RI Tahun 1945 sebagai hukum dasar yang tertinggi dalam negara, maka kebijakan politik hukum yang harus ditempuh oleh pemerintah terhadap pemerintah daerah dengan memberikan kewenangan kepada daerah untuk mengatur dan mengurus sendiri urusan pemerintahan, menurut asas otonomi dan tugas pembantuan, dan pemberian kewenangan itu harus diarahakan untuk mempercepat terwujudnya kesejahteraan masyarakat, melalui peningkatan pelayanan, pemberdayaan, dan peran serta masyarakat secara luas disegala bidang dalam sistim Negara Kesatuan Republik Indonesia.

Berdasarkan penjelasan Undang-Undang Nomor 32 Tahun 2004 tentang Pemerintahan daerah huruf $\mathrm{b}$ dimana Prinsip pemberian otonomi yang seluas-luasnya kepada daerah dalam arti bahwa daerah diberikan kewenangan mengatur dan mengurus semua urusan pemerintahan di luar yang menjadi urusan pemerintah yang ditetapkan dalam undang-undang. Sejalan dengan prinsip tersebut dilaksanakan pula prinsip otonomi yang nyata dan bertangung jawab. Prinsip otonomi nyata adalah suatu prinsip bahwa untuk menangani urusan

dengan sifat yang intervenvensionis dalam menentukan kebijakan Negara sehingga potensi dan aspirasi masyarakat tidak teragregasi dan terartikulasi secara proporsional, dan produk hukum yang dihasilkan bersifat konservatif/ortodoks yaitu produk hukum yang karakternya mencerminkan visi politik pemegang kekuasaan sangat dominant, sehingga proses pembuatan produk hukum tidak mengundang partisipasi dan aspirasi masyarakat secara sungguh-sungguh. 
pemerintahan dilaksanakan atas tugas, wewenang, dan kewajiban yang senyatanya telah ada dan berpotensi untuk tumbuh, hidup dan berkembang sesuai dengan potensi dan kekhasan daerah. Adapun yang dimaksud dengan otonomi yang bertanggung jawab adalah otonomi yang dalam penyelenggaraanya harus benar-benar sejalan dengan tujuan dan maksud pemberian otonomi yang pada dasarnya untuk memberdayakan daerah termasuk meningkatkan kesejahteraan rakyat yang merupakan bagian utama tujuan nasional.

\begin{tabular}{lrr}
\multicolumn{2}{c}{ Berdasarkan } & penjelasan \\
tersebut dapat dilihat bahwa & but \\
penyelenggaraan otonomi & daerah \\
harus tetap berorientasi pada & kesejahteraan rakyat dengan
\end{tabular}
memperhatikan beberapa hal antara lain :a. Kemampuan meningkatkan kinerja badan eksekutif dan badan legislatif dalam pelaksanaan otonomi daerah yang luas, nyata, dan bertanggung jawab, b. Pelaksanaan otonomi daerah tidak menyimpang dari amanat undang-undang tentang pemerintahan daerah, c. Mendukung sepenuhnya pelaksanaan otonomi yang telah digulirkan oleh pemerintah, d. Terwujudnya kelembagaan daerah yang mampu melaksanakan kewenangan daerah, kelembagaan dekonsentrasi, dan tugas pembantuan (medebewind), e. Memiliki perangkat daerah yang mempunyai kinerja tinggi, efisien, dan efektif dalam mengelola pembangunan daerah dan pelayanan publik menuju otonomi yang mandiri, f. Terciptanya hubungan kemitraan yang harmonis antara badan eksekutif dan badan legislatif daerah sehingga pelaksanaan otonomi yang demokratis berjalan dengan baik. ${ }^{6}$

Penyelenggaraan pemerintahan di Indonesia berdasarkan pendekatan kesisteman meliputi sistem pemerintahan pusat atau disebut pemerintah dan sistem pemerintahan daerah. Praktik penyelenggaraan pemerintahan dalam hubungan antarpemerintah, dikenal dengan konsep sentralisasi dan desentralisasi.

Konsep sentralisasi menunjukkan karakteristik bahwa semua kewenangan penyelenggaraan pemerintahan berada di pemerintah pusat, sedangkan sistem desentralisasi menunjukkan karakteristik yakni sebagian kewenangan urusan pemerintahan yang menjadi kewajiban pemerintah, diberikan kepada pemerintah daerah.

Pemerintahan daerah yang baik atau pemerintahan yang bersih $^{7}$ (good local governance) merupakan issue yang paling mengemuka dalam pembahasan kebijakan pemerintahan dewasa ini. Tuntutan gagasan yang dilakukan masyarakat kepada pemerintah untuk pelaksanaan penyelenggaraan pemerintahan daerah yang baik atau yang bersih adalah sejalan dengan meningkatnya pengetahuan masyarakat. Salah satu wujud tata kepemerintahan yang baik (good governance) itu terdapatnya citra pemerintahan yang demokratis. Prinsip demokrasi yang paling

\footnotetext{
${ }^{6}$ HAW. Widjaja, Penyelenggaraan Otonomi di Indonesia: Dalam Rangka Sosialisasi UU No. 32 tahun 2004 tentang Pemerintahan Daerah, Penerbit, P.T. Rajagrafindo Persada, Jakarta,2005, Hlm.15.

${ }^{7}$ Jimly Asshiddiqie, Penyelenggaraan Good Governance dalam RangkaPenegakan NilaiNilai Konstitusi, Menuju Negara Hukum Yang Demokratis, Sekretariat Jenderal dan Kepaniteraan Mahkamah Konstitusi, Jakarta, 2005, Hlm. 45.
} 
penting adalah meletakkan kekuasaan di tangan rakyat dimana pada tingkat terakhir rakyat memberikan ketentuan dalam masalah-masalah pokok mengenai kehidupannya, termasuk dalam menilai kebijaksanaan pemerintah dan negara, oleh karena kebijakan itu menentukan kehidupan rakyat. Untuk itu perlu memperkuat tuntutan tersebut maka perlu meningkatkan peran dan fungsi Pengawasan DPRD agar eksekutif dapat menjalankan tugasnya dengan baik. DPRD harus bisa menjadi alat kontrol bagi jalannya pemerintahan agar selalu sesuai dengan aspirasi masyarakat berdasarkan ketentuan perundangan yang berlaku.

\section{Pembahasan}

\subsection{Konsep dasar good governance}

Kata governance, diterjemahkan ke dalam bahasa Indonesia menjadi "tata pemerintahan". Dari pemahaman tersebut diperoleh gambaran bahwa governance adalah cara, bagaimana kekuasaan Negara digunakan untuk mengelola sumber daya ekonomi dan sosial guna pembangunan masyarakat. Governance juga bisa diartikan sebagai pelaksanaan otoritas politik ekonomi, administrasi untuk mengelola masalah nasional pada semua tingkatan. Persyaratan minimal untuk mencapai good governance adalah transparansi, akuntabilitas, partisipasi, penegak hokum, efektifitas, dan keadilan.

Keterlibatan masyarakat dalam setiap jenjang proses pengambilan keputusan, terutama menyangkut masyarakat, misalnya dalam pengelolaan sumberdaya alam, akan menjadi semacam aktifitas pendukung pengelolaan ( $\mathrm{co}$ management) yang terdiri atas suara rakyat dan tindakan-tindakan responsive pemerintah. Governance di dukung oleh tiga kaki yakni politik, ekonomi dan administrasi. Disamping itu governance atau tata pemerintahan memiliki tiga domain yaitu: 1) Negara atau pemerintahan (state); 2). Sektor swasta atau dunia usaha (private sektor), dan 3) masyarakat (society)

Ketiga domain diatas berada dalam kehidupan berbangsa, bernegara, dan bermasyarakat. Aktor pemerintah berperan dalam pembuatan kebijakan, pengendalian dan pengawasan. Sektor swasta lebih banyak sebagai penggerak ekonomi. Sedangkan masyarakat adalah sebagai obyek sekaligus subyek dari sektor pemerintah maupun swasta. Karena didalam masyarakat terjadi interaksi politik, ekonomi, dan sosial budaya. Governance yang dijalankan oleh ketiga domain tersebut tidak sekadar jalan melainkan harus masuk kategori baik (good). Perpaduan antara kata good dan governance menimbulkan kosakata baru yaitu good governance, yang dewasa ini menjadi sangat popular.

Hal ini mencakup mekanismemekanisme, proses-proses dan kelembagaan-kelembagaan yang dengan mana warga negara dan kelompok-kelompok mengartikulasikan kepentingannya, mendapatkan hak-haknya yang dijamin UndangUndang, melaksanakan kewajibannya dan mempertemukan perbedaan-perbedaan diantara mereka. Dari pengertian di atas maka Good Governance secara luas dimaknai sebagai adanya kecakapan yang diperlukan dalam sebuah negara untuk mengelola sumbersumberdayanya dan permsalahanpermasalahannya secara terbuka, transparan, bertangungjawab, kesetaraan perlakuan dan tanggap kepada kebutuhan rakyatnya.

\subsection{Fungsi Pengawasan DPRD terhadap pemerintah daerah}

Salah satu wujud tata kepemerintahan yang baik (good governance) itu terdapatnya citra 
pemerintahan yang demokratis. Prinsip demokrasi yang paling penting adalah meletakkan kekuasaan di tangan rakyat dimana pada tingkat terakhir rakyat memberikan ketentuan dalam masalah-masalah pokok mengenai kehidupannya, termasuk dalam menilai kebijaksanaan pemerintah dan negara, oleh karena kebijakan itu menentukan kehidupan rakyat.

Dalam sistem penyelenggaraan kenegaraan, Dewan Perwakilan Rakyat Daerah (DPRD) ditetapkan sebagai salah satu unsur penyelenggara pemerintahan Sebagaimana disebutkan pada Pasal 1 ayat (2) UU Nomor 32 Tahun 2004 adalah penyelenggara urusan DPRD dalam sistem dan prinsip Negara Kesatuan Republik Indonesia sebagaimana dimaksudkan dalam Undang-undang Dasar Negara Republik Indonesia Tahun 1945. Kedudukan DPRD sebagaimana yang diamanatkan oleh UU Nomor 32 Tahun 2004 implikasinya adalah antara kepala daerah dan DPRD benar-benar memiliki kesetaraan dan kesederajatan dan tidak ada dominasi salah satu diantara keduanya.

DPRD ditempatkan kedalam susunan pemerintahan daerah bersama kepala daerah, pola hubungan antara kepala daerah dan DPRD dilaksanakan secara sub ordinat dalam arti tidak adanya posisi tawar DPRD terhadap semua kebijakan yang diterbitkan oleh kepala daerah, sehingga eksistensi DPRD pada masa orde baru tidak lebih hanya sebagai stempel untuk melegalisasi setiap program dan kegiatan yang diajukan oleh kepala daerah, apalagi harus melakukan kontrol terhadap jalannya pemerintah daerah. Setelah runtuhnya rezim orde baru, DPRD yang ditetapkan sebagai lembaga legislatif daerah dengan menguatnya peran dan fungsi DPRD terutama fungsi kontrolnya terhadap pemerintah daerah.

Melihat eksistensi lembaga DPRD di era otonomi daerah, maka sudah sepantasnya DPRD dapat melaksanakan fungsi-fungsi yang dimilikinya secara lebih optimal. Salah satu fungsi yang dimiliki oleh DPRD adalah fungsi pengawasan. Fungsi pengawasan DPRD terhadap pemerintah daerah merupakan hal yang sangat penting untuk dioptimalkan. Hal ini didasari bahwa fungsi pengawasan DPRD terhadap pemerintah daerah memiliki peran yang sangat penting dalam mewujudkan Good Governance di Indonesia khususnya di daerah, karena bagaimanapun juga DPRD adalah lembaga perwakilan rakyat yang berada di daerah untuk menyampaikan aspirasi dan sudah sepantasnya rakyat juga ikut serta dalam mengawasi jalannya pemerintahan daerah yang tercermin dengan pelaksanaan fungsi pengawasan DPRD terhadap pemerintah daerah (eksekutif selaku pelaksana kebijakan). Dengan adanya pengawasan yang dilakukan oleh DPRD terhadap pemerintah daerah tentunya merupakan cerminan terlaksananya mekanisme checks and balances_dalam pengelolaan tata pemerintahan yang baik (good governace) di daerah.

Pasal 40 Undang-undang Nomor 32 Tahun 2004 disebutkan bahwa "DPRD merupakan lembaga perwakilan rakyat daerah dan berkedudukan sebagai unsur penyelenggaraan pemerintahan daerah". Dalam UU Nomor 27 Tahun 2009 juga dijelaskan bahwa DPRD berkedudukan sebagai unsur penyelengara pemerintahan daerah. 
Untuk wilayah provinsi maka disebut DPRD provinsi dan untuk wilayah kabupaten/kota maka disebut dengan DPRD kabupaten/kota.

Susunan DPRD terdiri atas anggota partai politik peserta pemilihan umum yang dipilih melalui pemilihan umum. Adapun alat kelengkapan DPRD terdiri atas ; pimpinan, Badan musyawarah, Komisi, Badan Legislasi Daerah, Badan Anggaran, Badan Kehormatan, dan alat kelengkapan lainnya yang diperlukan dan dibentuk oleh rapat paripurna. Dalam menjalankan tugasnya, maka alat kelengkapan dibantu oleh sekretariat yang berasal dari pegawai negeri sipil (PNS).

Dewan Perwakilan Rakyat

Daerah mempunyai fungsi :

a. Legislasi, merupakan fungsi DPRD untuk membentuk peraturan daerah bersama kepala daerah.

b. Anggaran, merupakan fungsi DPRD yang bersama-sama dengan pemerintah daerah menyusun dan menetapkan Anggaran Pendapatan dan Belanja Daerah, yang di dalamnya termasuk anggaran untuk pelaksanaan fungsi, tugas, dan wewenang DPRD.

c. Pengawasan, merupakan fungsi DPRD untuk melaksananakan pengawasan terhadap pelaksanaan undang-undang, peraturan daerah, dan keputusan kepala daerah serta kebijakan yang ditetapkan oleh Pemerintah daerah.

Selain itu, adapun tugas dan wewenang Dewan Perwakilan Rakyat Daerah meliputi :

a. Membentuk peraturan daerah yang dibahas dengan kepala daerah untuk mendapatkan persetujuan bersama;

b. Membahas dan memberikan persetujuan rancangan peraturan daerah mengenai anggaran pendapatan dan belanja daerah yang diajukan oleh kepala daerah;

c. Melaksanakan pengawasan terhadap pelaksanaan peraturan daerah dan peraturan perundangundangan lainnya, peraturan kepala daerah, APBD, kebijakan pemerintah daerah dalam melaksanakan program pembangunan daerah, dan kerjasama internasional di daerah;

d. Mengusulkan pengangkatan dan pemberhentian kepala daerah/wakil kepala daerah kepada Presiden melalui Menteri Dalam Negeri bagi DPRD provinsi dan kepada Menteri Dalam Negeri melalui Gubernur bagi DPRD kabupaten/kota;

e. Memilih wakil kepala daerah dalam hal terjadi kekosongan jabatan wakil kepala daerah;

f. Memberikan pendapat dan pertimbangan kepada pemerintah daerah terhadap rencana perjanjian internasional di daerah;

g. Memberikan persetujuan terhadap rencana kerja sama internasional yang dilakukan oleh pemerintah daerah;

h. Meminta laporan keterangan pertanggungjawaban kepala daerah dalam penyelenggaraan pemerintahan daerah;

i. Membentuk panitia pengawas pemilihan kepala daerah;

j. Melakukan pengawasan dan meminta laporan KPUD dalam penyelenggaraan pemilihan kepala daerah; 
k. Memberikan persetujuan terhadap rencana kerjaasama antar daerah dan dengan pihak ketiga yang membebani masyarakat dan daerah;

Undang-Undang Nomor 27 tahun 2009 tentang MPR, DPR, DPD dan DPRD, untuk melaksanakan tugas dan wewenangnya kepada DPRD diberikan diberikan beberapa hak dan kewajiban. Hak DPRD dalam melaksanakan tugas dan wewenangnya antara lain :

a. Hak Interpelasi, merupakan hak DPRD untuk meminta keterangan kepada kepala daerah mengenai kebijakan pemerintah daerah yang penting dan strategis serta berdampak luas pada kehidupan masyarakat dan bernegara;

b. Hak Angket, merupakan hak DPRD untuk melakukan penyelidikan terhadap kebijakan pemerintah daerah yang penting dan strategis serta berdampak luas pada kehidupan masyarakat, daerah, negara yang diduga bertentangan dengan ketentuan peraturan perundang-undangan;

c. Hak menyatakan pendapat, merupakan hak DPRD untuk menyatakan pendapat terhadap kebijakan pemerintah daerah mengenai kejadian luar biasa yang terjadi di daerah disertai dengan rekomendasi penyelesaiannya atau sebagai tindak lanjut pelaksanaan hak interpelasi dan hak angket.

Sementara itu bagi setiap anggota DPRD diberikan hak-hak sebagai berikut :

a. Mengajukan rancangan peraturan daerah;

b. Mengajukan pertanyaan;

c. Menyampaikan usul dan pendapat; d. Memilih dan dipilih;

e. Membela diri

f. Imunitas

g. Mengikuti orientasi dan pendalaman tugas

h. Protokoler

i. Keuangan dan administratif.

$$
\text { Adapun kewajiban bagi }
$$

anggota DPRD antara lain :

a. Memegang teguh dan mengamalkan pancasila;

b. Melaksanakan Undang-undang Dasar 1945 dan menaati peraturan perundang-undangan

c. Mempertahankan dan memelihara kerukunan nasional dan keutuhan Negara Kesatuan Republik Indonesia;

d. Mendahulukan kepentingan negara di atas kepentingan pribadi, kelompok, dan golongan;

e. Memperjuangkan peningkatan kesejahteraan rakyat di daerah;

f. Menaati prinsip demokrasi dalam penyelenggaraan pemerintahan daerah;

g. Manaati tata tertib dan kode etik;

h. Menjaga etika dan norma dalam hubungan kerja dengan lembaga lain dalam penyelenggaraan pemerintahan daerah kabupaten/kota;

i. Menyerap dan menghimpun aspirasi konstituen melalui keunjungan kerja secara berkala;Menampung dan menindaklanjuti aspirasi dan pengaduan masyarakat;

j. Memberikan pertanggungjawaban secara moral dan politis kepada konstituen di daerah pemilihannya.

Pengawasan DPRD melingkupi pengawasan terhadap pelaksanaan Perda dan peraturan perundangundangan lainnya, peraturan kepala daerah, APBD, kebijakan pemerintah 
daerah dalam melaksanakan program pembangunan daerah, dan kerja sama internasional di daerah. Bukan hanya itu, sebagai bagian dari pemerintahan daerah, DPRD sesungguhnya juga bertanggungjawab melakukan pengawasan terhadap layanan publik.

Tugas DPRD berkaitan dengan fungsi pengawasan pertama sebagai Melaksanakan pengawasan terhadap pelaksanaan peraturan daerah dan peraturan perundang-undangan lainnya, keputusan walikota/bupati, APBD, kebijakan pemerintah daerah dalam melaksanakan program pembangunan daerah dan kerjasama internasional (Pasal 78 (3) UU 22/2003 dan pasal 42 (3) UU 32/2004), kedua Meminta laporan keterangan pertanggungjawaban bupati/walikota dalam pelaksanaan tugas desentralisasi (Pasal 78 (6) UU 22/2003 dan pasal 42 (8) UU No. 32/2004), ketiga DPRD berwenang meminta pejabat negara tingkat kabupaten/kota, pejabat pemerintah kabupaten/kota, badan hukum, dan warga masyarakat untuk memberikan keterangan tentang sesuatu hal yang perlu ditangani demi kepentingan bangsa dan negara (Pasal 82 UU No. 22/2003).

Susunan pemerintahan daerah otonom meliputi DPRD dan pemerintah daerah. DPRD dipisahkan dari pemerintah daerah dengan maksud untuk lebih memberdayakan DPRD dan meningkatkan pertanggungjawaban pemerintah daerah kepada rakyat. Hak-hak DPRD cukup luas dan diarahkan untuk menyerap serta menyalurkan aspirasi masyarakat menjadi kebijakan daerah dan melakukan fungsi pengawasan. Fungsi DPRD dalam bidang pengawasan merupakan tindak lanjut dari fungsi-fungsi yang diperankan
DPRD sebelumnya yaitu fungsi legislasi dan fungsi anggaran, karena obyek-obyek yang diawasi DPRD kebanyakan merupakan kebijakankebijakan maupun program-program hasil dari fungsi legislasi maupun anggaran, oleh karena itu fungsi pengawasan merupakan sebuah kesatuan yang tak dapat dipisahkan dengan fungsi-fungsi lainnya.

$$
\text { Menurut Undang-undamg }
$$

Nomor 32 Tahun 2004 dengan kebijakan politik yang menganut prinsip kesetaraan dan checks and balances, maka otonomi daerah menggunakan seluas-luasnya kewenangan membuat kebijakan daerah untuk memberi pelayanan, peningkatan peran serta, prakarsa, dan penberdayaan masyarakat yang bertujuan pada peningkatan kesejahteraan rakyat. Untuk menghindari adanya konflik politik antara kepala Daerah dengan DPRD maka perlu hubungan keduanya dijalankan melalui prinsip "Check and Balances" artinya adanya keseimbangan serta merta adanya pengawasan terus menerus terhadap kewenangan yang diberikannya . Dengan demikian anggota DPRD dapat dikatakan memiliki akuntabilitas, manakala memiliki “ rasa tanggung jawab " dan "kemampuan" yang profesional dalam menjalankan peran dan fungsinya tersebut. Terkait dengan hal ini berpendapat bahwa mekanisme "Check and Balances" memberikan peluang eksekutif untuk mengontrol legislatif. Walaupun harus diakui oleh DPRD (Legislatif) memiliki posisi politik yang sangat kokoh dan seringkali tidak memiliki akuntabilitas politik karena berkaitan erat dengan sistem pemilihan umum yang dijalankan. Dengan adanya keseimbangan hak dan kewenangan 
tersebut antara eksekutif dan legislatif diharapkan korupsi yang marak terjadi di DPRD (legislatif) dapat berkurang seiring dengan pematangan demokrasi dalam kehidupan masyarakat. Terwujudnya "Clean and good governance" merupakan harapan semua masyarakat. tujuan utama pengawasan bermaksud untuk memahami apa yang salah demi perbaikan di masa datang, dan mengarahkan seluruh kegiatankegiatan dalam rangka pelaksanaan dari pada suatu rencana sehingga dapat diharapkan suatu hasil yang maksimal. Esensinya membantu agar sasaran dapat dicapai secara dini menghindari terjadinya penyimpangan, penyalahgunaan wewenang, pemborosan dan pembocoran dana-dana pembangunan.

Di dalam suatu sistem Pemerintahan Daerah, pengawasan merupakan suatu usaha penertiban untuk menjamin terealisasinya segala ketentuan Undang-Undang, peraturan keputusan kebijaksanaan dan ketentuan daerah itu sendiri. Hasil pengawasan dapat dijadikan bahan informasi atau umpan balik dari penyempurnaan baik bagi rencana itu sendiri maupun dalam mewujudkan rencana itu sendiri. Pengawasan dalam organisasi pemerintah diperlukan agar organisasi pemerintahan dapat bekerja secara efisien, efektif dan ekonomis. Pengawasan disini merupakan unsur penting untuk meningkatkan pendayagunaan aparatur negara dalam melaksanakan tugas-tugas umum pemerintahan dan pembangunan menuju terwujudnya pemerintahan yang bersih dan berwibawa. fungsi pengawasan merupakan suatu mekanisme peringatan dini (early warning system), untuk mengawal pelaksanaan aktivitas mencapai tujuan dan sasaran.

Manfaat pengawasan adalah :
1. Terlaksanannya kebijakan pemerintah daerah berjalan sesuai dengan rencana;

2. Dapat dilakukan tindakan koreksi yang cepat dan tepat terhadap penyimpangan dan penyelewengan yang ditemukan terhadap kebijakan pemerintah daerah yang sudah direncankan

3. Menumbuhkan motivasi, perbaikan, pengurangan, peniadaan penyimpangan terhadap kebijakan pemerintah daerah.

4. Untuk mencari jalan keluar bila ternyata dijumpai kesulitankesulitan, kelemahan-kelemahan, atau kegagalan-kegagalan kebijakan atau program pemerintah daerah ke arah perbaikan

Pengawasan adalah mengusahakan agar apa yang direncanakan sesuai dengan apa yang diharapakan atau menjadi kenyataan, maka sangat diperlukan adanya pengawasan sebagai alat pengamanan dari perencanaan dengan tujuan agar kegiatan yang direncanakan dapat berjalan dengan hasil yang maksimal seperti yang menjadi harapan bersama. Praktik fungsi pengawasan yang dilakukan oleh DPRD terhadap Pemerintah Daerah dalam rangka mewujudkan good governancet agar dapat mencapai tujuannya tersebut. DPRD harus dapat Memaknai secara benar fungsi dan tujuan pengawasan, sehingga dapat menjadi mekanisme check \& balance yang efektif, melakukan optimalisasi pengawasan agar dapat memberikan dapat 
memberikan pengaruh yang positif sesuai dengan yang diharapkan pada pengelolaan pemerintahan daerah, melakukan penyusunan agenda pengawasan DPRD, Perumusan standar, sistem, dan prosedur baku pengawasan DPRD, serta melibatkan partisipasi masyarakat dalam proses pengawasan.

Pengawasan yang dapat dilakukan DPRD terhadap Pemerintah daerah dalam rangka mewujudkan good governance antara lain:

\section{Pengawasan Preventif}

pada tahap persiapan dan perencanaan suatu kegiatan atau kebijakan pemerintah daerah. Pengawasan ini bertujuan pada aspek pencegahan dan perbaikan. Misalnya dengan mengadakan pengawasan terhadap persiapan-persiapan kerja, rencana anggaran, rencana penggunaan tenaga, dan sumbersumber lain.

\section{Pengawasan Refresif}

Pengawasan terhadap prosesproses aktivitas pemerintah daerah. Pengawasan bertujuan menghentikan pelanggaran dan mengembalikan pada keadaan semula, baik disertai atau tanpa sanksi. Bentuk pengawasan yang dilakukan melalui post-audit dengan melakukan pemeriksaan terhadap pelaksanaan ditempat (inspeksi), meminta laporan pelaksanaan, dan sebagainya.

Pengawasan DPRD pada saat pembahasan anggaran. Dalam pengawasan pendahuluan ini DPRD sangat diharapkan perannya dalam meneliti setiap usulan anggaran khususnya dari penyedia layanan publik, baik dari sisi harga layanan, output maupun outcomes dari setiap jenis layanan. Sangat diharapkan anggota DPRD melakukan pengawasan sejak tahap perencanaan. yang dibuat oleh pihak eksekutif. Dan dari alokasi anggaran untuk pelayanan publik juga bisa diketahui apakah pemerintah daerah akan memberikan pelayanan publik kepada masyarakat secara memadai atau tidak. Selanjutnya untuk memastikan layanan publik berjalan sesuai standar yang ditetapkan dan memenuhi harapan masyarakat selama pelayanan dilakukan dalam jangka waktu tertentu. Pengawasan juga bisa diarahkan terhadap pelaksanaan anggaran atas layanan publik atau masa perjalannya sebuah peraturan. serta memastikan layanan publik berjalan sesuai harapan, juga diperuntukkan atas evaluasi terhadap target yang direncanakan. Pengawasan diharapkan akan menghasilkan rekomendasi mempertahankan, memperbaiki atau meningkatkan kualitas layanan.

Berdasarkan pengawasan tersebut DPRD dapat melakukan tindakan antara lain. Tindakan perbaikan secara adminsitrasi misalnya pembuatan raperda baru. Penghentian proyek maupun program. Selanjutnya berupa tindakan hukum. Khusus untuk tindak lanjut secara hukum ini DPRD harus menyerahkan otoritas secara penuh pada otoritas yang berwenang yaitu kepolisian, kejaksaan, dan pengadilan atau kepala lembagalembaga/komisi pelayanan publik bagi daerah yang memiliki lembaga ombudsman atau Komisi Pelayanan Publik, DPRD dapat melakukan tindakan politik yakni sesuai dengan Pasal 43 UU No. 32/2004 menyebutkan bahwa DPRD sesungguhnya memiliki hak legal 
yang sewaktu-waktu dapat digunakan sebagai tindakan politik dalam mengukur kinerja pemerintah daerah. Bahkan tindakan politik tersebut bisa berimplikasi terhadap tindakan penegakan hukum.

\section{Pentup}

\section{Simpulan}

Fungsi pengawasan yang dilakukan oleh DPRD terhadap Pemerintah Daerah dalam rangka mewujudkan good governancet agar dapat mencapai tujuanny. DPRD harus dapat Memaknai secara benar fungsi dan tujuan pengawasan, sehingga dapat menjadi mekanisme check \& balance yang efektif, melakukan optimalisasi pengawasan agar dapat memberikan dapat memberikan pengaruh yang positif sesuai dengan yang diharapkan pada pengelolaan pemerintahan daerah, melakukan penyusunan agenda pengawasan DPRD, Perumusan standar, sistem, dan prosedur baku pengawasan DPRD, serta melibatkan partisipasi masyarakat dalam proses pengawasan.

Sebab itu disarankan perlunya keikutsertaan masyarakat dalam melakukan pengawasan sehingga dalam penerapan kebijakan pemerintah daerah dapat berjalan dengan baik serta pererlu disusun pedoman pengawasan oleh DPRD sehingga fungsi pengawasan tersebut dapat berjalan lebih terarah.

\section{Daftar Pustaka}

Bagir Manan, Menyongsong Fajar Otonomi Daerah. Pusat Studi Hukum (PSH), Fakultas Hukum UII Yogyakarta, 2001.

HAW. Widjaja, Penyelenggaraan Otonomi di Indonesia: Dalam
Rangka Sosialisasi UU No. 32

Tahun $2004 \quad$ tentang

Pemerintahan Daerah,

Penerbit, P.T. Rajagrafindo

Persada, Jakarta,2005

Jimly Asshiddiqie, Penyelenggaraan

Good Governance dalam

RangkaPenegakan Nilai-Nilai

Konstitusi, Menuju Negara

Hukum Yang Demokratis,

Sekretariat Jenderal dan

Kepaniteraan Mahkamah

Konstitusi, Jakarta, 2005.

Juanda, Hukum Pemerintahan

Daerah: Pasang Surut

Kewenangan antara DPRD dan

Kepala Daerah, Penerbit P.T.

Alumni, Bandung, 2004

Moh Mahfud MD, Pergulatan Politik dan Hukum Di Indonesia, Penerbit Gama Media, Yogyakarta, 1999.

M. Laica Marjuki, Berjalan -Jalan di Ranah Hukum: Otonomi Daerah Dalam Perspektif Negara Kesatuan, Sekjen MKRI RI, 2006.

Undang-undang Dasar 1945

Undang-undang Nomor 12/ 2011 tentang Pembentukan Peraturan Perundang-perundangan.

Undang-undang Nomor 27/2009 Tentang MPR, DPR, DPD, dan DPRD.

Undang-undang Nomor 32/2004 Tentang Pemerintah Daerah sebagaimana diubah dengan Undang-undang Nomor 12 Tahun 2008.

PP Nomor 23/2007 Tentang Pedoman Tata Cara Pengawasan Atas Penyelenggaraan Pemerintahan Daerah 